\title{
Penerapan Teknik Bertanya Dalam Pembelajaran PKn Berbasis Masalah Sosial Untuk Meningkatkan Aktivitas Belajar Siswa
}

\author{
Endang Subarna \\ SMPN 1 Cikoneng Kecamatan Cikoneng Kabupaten Ciamis Jawa Barat \\ Email : ndangs63@gmail.com
}

\begin{abstract}
Civics lesson is one of the social fields that has a very important role in improving the quality of human resources. The learning process in school can affect the level of one's welfare, as well as the quality of learning implementation of Citizenship Education (Civics). In the process of learning to teach the target to be achieved not only the goal is achieved but more than that is to familiarize students with good learning process, which is high activity that can improve students' own reasoning power and increase student activity in learning. Civic learning has tended to be limited to giving the ability to memorize the concept but in reality the Civic learning is very important in everyday life. Reconstruction of Civic learning oriented on social issues is basically done so that the subject matter of Civics is not only focused on the material but can provide the social skills that students need to solve social problems in their daily life. In this case critical questioning technique aims to facilitate students to think critically and can find social problems in the environment as well as find alternative solutions because the way of asking students in general is still considered difficult because of the mental influence they have and the influence of the surrounding environment which resulted in students not confident and the stimulus provided by the teacher is still low in growing the courage of students in asking questions. As a classroom learning therapy then Classroom Action Research can be used as one way to overcome the difficulties of teaching teachers in the classroom. In this case Class Action Research is intended to solve learning problems and to produce quality learning that includes awareness of the values, effectiveness and creativity of learners in learning, so that problems in learning can be resolved properly. With the questioning technique is expected to create an interactive atmosphere of learning interwoven and educational by positioning students as an important figure in learning.
\end{abstract}

Keyword : questioning techniques, based on social issues, learning activities.

Abstract - Mata pelajaran PKn merupakan salah satu bidang sosial yang mempunyai peranan yang sangat penting dalam meningkatkan kualitas sumber daya manusia. Proses pembelajaran di sekolah dapat mempengaruhi tingkat kesejahteraan seseorang, begitu pula dengan kualitas pelaksanan pembelajaran Pendidikan Kewarganegaraan (PKn). Dalam proses belajar mengajar target yang harus dicapai bukan hanya semata-mata tujuan itu tercapai akan tetapi lebih dari itu yaitu membiasakan siswa belajar dengan proses yang baik, yang berkadar aktivitas tinggi yang dapat meningkatkan daya 
penalaran siswa itu sendiri dan meningkatkan aktivitas siswa dalam belajar. Pembelajaran PKn selama ini cenderung hanya sebatas memberikan kemampuan menghapal tentang konsep saja tetapi pada kenyataannya pelajaran PKn sangat penting dalam kehidupan sehari-hari. Rekonstruksi terhadap pembelajaran PKn yang berorientasi pada masalah-masalah sosial pada dasarnya dilakukan agar materi pelajaran PKn tidak hanya difokuskan pada materi saja tetapi dapat memberikan keterampilan sosial yang diperlukan siswa untuk memecahkan masalah-masalah sosial dalam kehidupan sehari-hari. Dalam hal ini teknik bertanya secara kritis ini bertujuan untuk memfasilitasi siswa berfikir kritis dan dapat menemukan masalah-masalah sosial di lingkungan sekitarnya sekaligus menemukan alternatif pemecahannya karena cara bertanya siswa pada umumnya masih dianggap sulit hal ini disebabkan karena pengaruh mental yang mereka miliki dan pengaruh lingkungan sekitar yang mengakibatkan siswa tidak percaya diri dan rangsangan yang diberikan oleh guru masih rendah dalam menumbuhkan keberanian siswa dalam bertanya. Sebagai terapi pembelajaran di kelas maka Penelitian Tindakan Kelas (PTK) dapat dijadikan sebagai salah satu cara mengatasi kesulitan mengajar guru di kelas. Dalam hal ini Penelitian Tindakan Kelas dimaksudkan untuk memecahkan masalah pembelajaran dan untuk menghasilkan kualitas pembelajaran yang mencakup penyadaran akan nilai-nilai, efektifitas dan kreatifitas peserta didik dalam pembelajaran, sehingga masalah dalam pembelajaran dapat teratasi dengan baik. Dengan teknik bertanya diharapkan dapat menciptakan suasana pembelajaran yang terjalin secara interaktif dan edukatif dengan memposisikan siswa sebagai sosok yang penting dalam pembelajaran.

Kata Kunci : teknik bertanya, berbasis masalah sosial, aktivitas belajar.

\section{Pendahuluan}

Pendidikan merupakan salah satu kebutuhan hidup yang sangat penting bagi masyarakat. Hal ini dikarenakan tingkat kesejahteraan seseorang yang tinggal di masyarakat dipengaruhi oleh kualitas pendidikan yang didapatkannya di sekolah. Dengan kata lain proses pembelajaran di sekolah dapat mempengaruhi tingkat kesejahteraan seseorang, begitu pula dengan kualitas pelaksanaan pembelajaran Pendidikan Kewarganegaraan (PKn). Mata pelajaran PKn merupakan salah satu bidang sosial yang mempunyai peranaan yang sangat penting dalam meningkatkan kualitas sumber daya manusia.

Dalam proses belajar mengajar target yang harus dicapai bukan hanya sematamata tujuan itu tercapai akan tetapi lebih dari itu yaitu membiasakan siswa belajar dengan proses yang baik, yang berkadar aktivitas tinggi yang dapat meningkatkan daya penalaran siswa itu sendiri dan meningkatkan aktivitas siswa dalam belajar.

Dari hasil wawancara dan observasi yang dilakukan diketahui bahwa kejenuhan dan ketidak aktifan siswa untuk bertanya serta berfikir kritis pada mata pelajaran PKn di karenakan beberapa hal, diantaranya yaitu:

1. Dari komponen Guru

Selama pembelajaran berlangsung peran guru terlihat cukup mendominasi, guru hanya memberikan banyak materi dan ceramah tanpa mengoptimalkan kemampuan siswa untuk berpartisipasi aktif dengan cara bertanya. Guru hanya terfokus pada materi, dan kurang membawa masalah-masalah sosial untuk merangsang siswa berfikir kritis dan bertanya, sehingga siswa kurang akan pengetahuan terhadap masalah yang terjadi di luar kelas.

2. Dari komponen siswa 
Banyak siswa yang motivasi belajarnya kurang terhadap pelajaran $\mathrm{PKn}$, hal ini selain disebabkan strategi dan metode yang disampaikan kurang menarik motivasi siswa. Adapun keaktifan hanya dimiliki oleh siswa tertentu saja sedangkan siswa lain bersikap pasif, acuh dan kurang memperhatikan terhadap pelajaran yang diberikan oleh guru. Dalam proses belajar mengajar yang disampaikan oleh guru masih dominan menggunakan metode ceramah dan tanya jawab dua arah (two way), guru tidak pernah membawa masalah yang sosial, isu-isu yang terjadi di luar kelas. Dari paparan di atas jelaslah bahwa pembelajaran PKn selama ini cenderung hanya sebatas memberikan kemampuan menghapal tentang konsep saja tetapi pada kenyataannya pelajaran PKn sangat penting dalam kehidupan sehari-hari. Rekonstruksi terhadap pembelajaran PKn yang berorientasi pada masalah-masalah sosial pada dasarnya dilakukan agar materi pelajaran PKn tidak hanya difokuskan pada materi saja tetapi dapat memberikan keterampilan sosial yang diperlukan siswa untuk memecahkan masalah-masalah sosial dalam kehidupan sehari-hari.

Dalam hal ini teknik bertanya secara kritis ini bertujuan untuk memfasilitasi siswa berfikir kritis dan dapat menemukan masalah-masalah sosial di lingkungan sekitarnya sekaligus menemukan alternatif pemecahannya karena cara bertanya siswa pada umumnya masih dianggap sulit hal ini disebabkan karena pengaruh mental yang mereka miliki dan pengaruh lingkungan sekitar yang mengakibatkan siswa tidak percaya diri dan rangsangan yang diberikan oleh guru masih rendah dalam menumbuhkan keberanian siswa dalam bertanya.

Secara universal guru akan selalu bertanya kepada siswanya, cara bertanya yang dilakukan oleh guru mempunyai pengaruh yang sangat penting tidak hanya pada hasil belajar siswa tetapi pada suasana kelas baik sosial maupun emosional. Dengan bertanya akan membantu siswa belajar dengan kawannya membantu siswa lebih sempurna dalam menerima informasi atau dapat mengembangkan keterampilan kognitif tingkat tinggi. Dengan demikian guru tidak hanya akan belajar bagaimana "bertanya" yang baik dan benar, tetapi juga belajar bagaimana mempengaruhi siswa dalam bertanya di kelas.

Penelitian dilakukan di kelas VII A, karena menurut keterangan guru mitra, kemampuan akademik siswa-siswinya sangat kurang. Di kelas ini siswa yang memiliki kemampuan akademiknya berada di bawah rata-rata, dari jumlah siswa 36 orang. Untuk melihat lebih rinci mengenai kemampuan akademik yang dimiliki oleh siswa kelas VII A dapat dilihat pada tabel di bawah ini:

\section{TABEL 1 \\ KEMAMPUAN AKADEMIK SISWA KELAS VII A}

\begin{tabular}{|c|c|c|}
\hline Nilai & $\begin{array}{c}\text { Jumlah } \\
\text { Siswa }\end{array}$ & $\%$ \\
\hline $\begin{array}{c}\text { Di atas rata-rata } \\
(70-90)\end{array}$ & - & - \\
\hline Rata-rata (70) & 5 & $13,89 \%$ \\
\hline $\begin{array}{c}\text { Di bawah rata- } \\
\text { rata } \\
(60-65)\end{array}$ & 31 & $86,11 \%$ \\
\hline Jumlah & 36 & $100 \%$ \\
\hline
\end{tabular}

Dalam proses pembelajaran di kelas, keaktifan hanya didominasi oleh siswa tertentu saja sedangkan sebagian siswa lain kurang aktif dalam kegiatan belajar, diantaranya yaitu ada siswa yang pendiam, kurang memperhatikan penjelasan guru, tidak serius dalam mengikuti pelajaran serta kurang aktif dalam diskusi dan bertanya kepada guru, hal ini memicu 
peneliti untuk meneliti kelas VII A agar dapat menjadikan pembelajaran di kelas lebih baik.

Sebagai terapi pembelajaran di kelas maka Penelitian Tindakan Kelas (PTK) dapat dijadikan sebagai salah satu cara mengatasi kesulitan mengajar guru di kelas. Dalam hal ini Penelitian Tindakan Kelas dimaksudkan untuk memecahkan masalah pembelajaran dan untuk menghasilkan kualitas pembelajaran yang mencakup penyadaran akan nilai-nilai, efektifitas dan kreatifitas peserta didik dalam pembelajaran, sehingga masalah dalam pembelajaran dapat teratasi dengan baik. Maka berdasarkan penjabaran di atas, teknik bertanya memiliki peranan yang sangat sentral dalam pembelajaran. Pertanyaan dalam proses belajar mengajar merupakan sesuatu hal yang penting karena dapat menstimulus siswa u ntuk berpikir. Selain itu, biasanya siswa yang telah menyadari akan adanya pertanyaan dari guru pada saat proses pembelajaran akan lebih mempersiapkan diri untuk menghadapi pelajaran tersebut. Setidaknya siswa tidak datang ke kelas dalam keadaan tidak memiliki pengetahuan sedikitpun karena siswa telah mempelajari materi sebelum memasuki kelas.

Teknik pembelajaran ini diharapkan dapat menjadi solusi untuk menciptakan pembelajaran yang lebih bermakna, khususnya bagi siswa. Oleh karena itu, peneliti ingin mengangkat tema mengenai pentingnya penerapan teknik bertanya dalam pembelajaran. Dengan teknik bertanya diharapkan dapat menciptakan suasana pembelajaran yang terjalin secara interaktif dan edukatif dengan memposisikan siswa sebagai sosok yang penting dalam pembelajaran. Adapun judul yang peneliti angkat dalam penelitian ini yaitu "PENERAPAN TEKNIK BERTANYA DALAM PEMBELAJARAN PKn BERBASIS MASALAH SOSIAL UNTUK
MENINGKATKAN AKTIVITAS BELAJAR SISWA"(Penelitian Tindakan Kelas di kelas VII SMPN 1 Cikoneng Kecamatan Cikoneng Kabupaten Ciamis Jawa Barat).

Berdasarkan uraian di atas, maka untuk memudahkan dan mengarahkan pembahasan secara spesifik, peneliti merumuskan permasalahan yang berhubungan dengan penerapan teknik bertanya dalam mengkonstruksi pembelajaran PKn yang berorientasi pada masalah-masalah sosial ke dalam beberapa rumusan masalah yaitu sebagai berikut:

1. Bagaimanakah guru merangsang siswa bertanya dalam pembelajaran PKn berbasis masalah sosial untuk meningkatkan aktivitas belajar siswa?

2. Bagaimanakah guru mengaplikasikan pola penerapan teknik bertanya dalam pembelajaran PKn berbasis masalah sosial untuk meningkatkan aktivitas belajar siswa?

3. Kendala-kendala apa yang dihadapi oleh guru selama mengaplikasikan penerapan teknik bertanya dalam pembelajaran PKn berbasis masalah sosial untuk meningkatkan aktivitas belajar siswa?

4. Upaya-upaya apa yang dilakukan oleh guru dalam mengatasi kendala yang dihadapi selama mengaplikasikan penerapan teknik bertanya dalam pembelajaran PKn berbasis masalah sosial sebagai upaya meningkatkan aktivitas belajar siswa?

Tujuan yang peneliti harapkan dari Penelitian Tindakan Kelas ini adalah :

1. Untuk mengetahui sampai sejauh mana kemampuan guru untuk merangsang siswa dalam bertanya pada proses kegiatan belajar mengajar.

2. Mengaplikasikan penerapan teknik bertanya dalam pembelajaran PKn berbasis masalah sosial untuk meningkatkan aktivitas belajar siswa. 
3. Mengungkapkan kendala-kendala yang di hadapi selama mengaplikasikan penerapan teknik bertanya dalam pembelajaran PKn berbasis masalah sosial untuk meningkatkan aktivitas belajar siswa.

4. Untuk mengetahui upaya-upaya yang dilakukan oleh guru dalam mengatasi kendala yang dihadapi selama mengaplikasikan penerapan teknik bertanya dalam pembelajaran PKn berbasis masalah sosial sebagai upaya meningkatkan aktivitas belajar siswa.

Pelaksanaan Penelitian Tindakan Kelas ini diharapkan akan memberikan beberapa manfaat:

\section{Secara Teoritis}

Secara teoritis penelitian ini diharapkan dapat memberikan sumbangan pengetahuan bagi peningkatan mutu pelajaran dan efektifitas pelajaran PKn di sekolah.

b. Praktis

- Bagi guru, hasil penelitian ini di harapkan dapat bermanfaat untuk membantu mengatasi permasalahan pembelajaran yang mereka hadapi serta menambah wawasan, keterampilan dan teknik mengajar dan memberikan kontribusi yang baik agar proses mengajar ke depan lebih baik.

- Bagi siswa, diharapkan siswa dapat merasakan proses belajar yang menyenangkan, menumbuhkan rasa percaya diri untuk bertanya, mengembangkan kemampuan berfikir kritis dan mampu menggali potensi yang dimilikinya untuk menghadapi berbagai tantangan sosial yang dihadapinya, serta menambah wawasan akan masalah atau isu-isu yang sedang terjadi di luar proses belajar.

- Bagi sekolah yang diteliti, mudahmudahan penelitian ini dapat memberikan sumbangan dalam upaya meningkatkan mutu pelajaran PKn di sekolah.

- Bagi peneliti, penelitian ini diharapkan dapat menjadi pengalaman dan memberikan wawasan sebagai pendidik yang profesional.

\section{METODE PENELITIAN}

\section{A. Setting dan Subjek Penelitian}

Lokasi penelitian ini dilaksanakan di kelas VII A SMP Negeri 1 Cikoneng, Jl. Margaluyu Kecamatan Cikoneng Kabupaten Ciamis Jawa Barat. Yang menjadi dasar pertimbangan dipilihnya sekolah tersebut sebagai lokasi dalam penelitian adalah, peneliti merupakan pengajar di SMP Negeri 1 Cikoneng, kelas VII A merupakan kelas yang kurang dalam aktivitas belajar sehingga hasil belajarnya pun sangat rendah, dan peneliti mencoba untuk memecahkan permasalahan yang terjadi di kelas VII A SMP Negeri 1 Cikoneng.

Adapun yang menjadi subjek penelitian adalah siswa kelas VII A berjumlah 36 orang siswa laki-laki. Alasan peneliti memilih kelas VII A adalah karena dikelas ini di temukan permasalahan terkait dengan aktivitas belajar dan hasil belajar siswa yang rendah, sehingga harus diperbaiki dalam proses belajar mengajar dikelas VII A.

Penelitian tindakan kelas ini dilaksanakan pada semester ganjil tahun ajaran 2015/2016. Secara umum penelitian tindakan ini terbagi ke dalam dua siklus dengan setiap siklusnya terdiri dari 2 pertemuan yang sesuai dengan target yang harus dicapai pada setiap siklusnya. Adapun waktunya sebagai berikut:

1. Persiapan penelitian tanggal 10 s.d 31 Agustus 2015

2. Pelaksanaan penelitian sebagai berikut: 
- Siklus I pertemuan dilaksanakan tanggal September 2015,

- Siklus I pertemuan 2 dilaksanakan tanggal 10 September 2015,

- Siklus II pertemuan 1 dilaksanakan tanggal 17 September 2015,

- Siklus II pertemuan 2 dilaksanakan tanggal 24 September 2015,

3. Pengolahan dan penggandaan hasill penelitian tanggal 25 September s.d 17 Oktober 2015

4. Seminar hasil penelitian tanggal 24 Oktober 2015

\begin{tabular}{|c|c|c|c|}
\cline { 2 - 4 } 1 & 2 & $61-75$ & Cukup \\
\hline 3 & $76-90$ & Tinggi \\
\hline 4 & $91-100$ & Tinggi Sekali \\
\hline
\end{tabular}

\section{TABEL 3 \\ KRITERIA KETUNTASAN BELAJAR SISWA}

\begin{tabular}{|c|c|c|}
\hline No & NiIai & Kriteria \\
\hline 1 & $<70$ & $\begin{array}{c}\text { Tidak Tuntas } \\
\text { (Remidi) }\end{array}$ \\
\hline 2 & $70-90$ & Tuntas \\
\hline 3 & $91-100$ & Pengayaan \\
\hline
\end{tabular}

\section{HASIL PENELITIAN DAN PEMBAHASAN}

Berdasarkan hasil penelitian mengenai

5. Pelaporan hasil penelitian tanggal 29 Oktober 2015

\section{B. Prosedur Penelitian}

Prosedur penelitian terdiri dari tahap persiapan penelitian, tahap pelaksanaan penelitian : tahap perencanaan dan tahap pelaksanaan.

\section{Teknik Pengumpulan Data}

Teknik pengumpulan data terdiri dari observasi, wawancara, studi dokumentasi, studi literatur.

\section{Teknik Pengolahan dan Analisis Data}

Teknik pengumpulan data terdiri dari reduksi data, display data, mengambil kesimpulan dan verivikasi data.

\section{E. Indikator Keberhasilan}

Penelitian tindakan kelas ini dianggap berhasil apabila adanya indikator penilaian penguasaan materi dan kriteria ketuntasan belajar siswa, yaitu:

TABEL 2

KRITERIA PENILAIAN PENGUASAAN MATERI

\begin{tabular}{|c|c|c|}
\hline No. & NiIai & Kriteria \\
\hline 1 & $<60$ & Rendah \\
\hline
\end{tabular}
pembelajaran PKn berbasis masalah sosial untuk meningkatkan aktivitas siswa, yang dilaksanakan selama 2 siklus 4 pertemuan di kelas VII A SMP Negeri 1 Cikoneng Kabupaten Ciamis, sebagai hasil penelitian dapat peneliti simpulkan sebagai berikut;

\section{A. Hasil Observasi Kegiatan Guru dan Siswa dalam Pembelajaran}

Berdasarkan hasil pengamatan observer selama 2 siklus 4 pertemuan, menunjukan adanya perbaikan dan peningkatan presentase keterlaksanaan pembelajaran yang dilakukan oleh guru. Upaya guru untuk menarik perhatian siswa agar aktif di dalam kegiatan pembelajaran dapat terlihat dari hasil pengamatan yang dilakukan oleh pengamatan. Hasil presentase keterlaksanaan pembelajaran siklus I pertemuan 1 baru mencapai $69,05 \%$, siklus I pertemuan 2 meningkat menjadi $78,57 \%$, siklus II pertemuan 1 mencapai $88,10 \%$, dan siklus II pertemuan 2 meningkat kembali menjadi 95,24\%.

Selain itu upaya guru untuk meningkatkan keaktifan siswa berdampak pada keaktifan siswa dalam kegiatan pembelajaran. Berdasarkan hasil pengamatan observer terhadap aktifitas 
siswa siklus I pertemuan 1 presentase mencapai $38,46 \%$, siklus I pertemuan 2 meningkat 61,54 , siklus II pertemuan 1 mencapai $89,74 \%$, dan siklus II pertemuan 2 meningkat menjadi $94,87 \%$. Dari hasil observasi diperoleh hasil bahwa melalui penerapan teknik bertanya dalam pembelajaran PKn berbasis masalah social dijadikan sebagai alternative bagi guru Pendidikan Kewarganegaraan (PKn) dalam menyampaikan materi, sehingga suasana belajar menjadi lebih bervariasi, menarik bagi siswa dan dapat mendorong siswa untuk terlibat aktif dalam pembelajaran. Untuk melihat gambaran peningkatan presentase pembelajaran aktivitas guru dan siswa dapat dilihat pada grafik berikut ini.

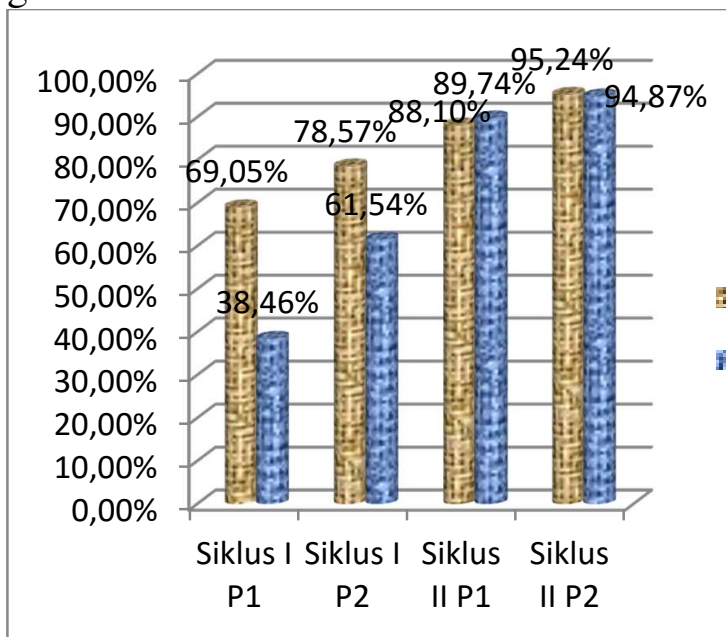

Gambar 1. Rekapitulasi Presentase Hasil Pengamatan Aktivitas Guru dan Siswa Siklus I dan Siklus II

\section{B. Hasil Analisis Belajar Siswa Setelah Penerapan Teknik Bertanya dalam Pembelajaran PKn Berbasis Masalah Sosial untuk Meningkatkan Aktivitas Siswa}

Pada setiap akhir pembelajaran guru memberikan lembar tes evaluasi kepada siswa, untuk melihat kemampuan siswa memahami pembelajaran setelah diterapkannya teknik bertanya dalam pembelajaran PKn berbasis masalah sosial. Berdasarkan analisis hasil tes siswa selama 4 pertemuan, menunjukan adanya peningkatan rata-rata nilai dan ketuntasan belajar siswa yang cukup baik. Rata-rata nilai siswa siklus I pertemuan 1 mencapai 58,19 , siklus I pertemuan 2 rata-rata nilai 65,28 (meningkat sebesar 7,08 dari siklus I pertemuan 1), siklus II pertemuan 1 ratarata nilai 70,56 (meningkat sebesar 5,28 dari siklus I pertemuan 2), dan siklus II pertemuan 2 rata-rata nilai 74,86 (meningkat sebesar 4,31 dari siklus II pertemuan 1).

Sedangkan ketuntasan belaja siswa siklus I pertemuan 1 baru mencapai 9 orang siswa (25\%), siklus I pertemuan 2 mencapai 16 orang siswa $(44,44 \%)$, siklus II pertemuan 1 meningkat menjadi 22 siswa $(61,11 \%)$, dan siklus II pertemuan 2 mencapai 30 orang siswa $(83,33 \%)$. Untuk melihat gambaran peningkatan nilai ratarata dan presentase ketuntasan hasil tes belajar siswa dapat dilihat pada grafik berikut ini.

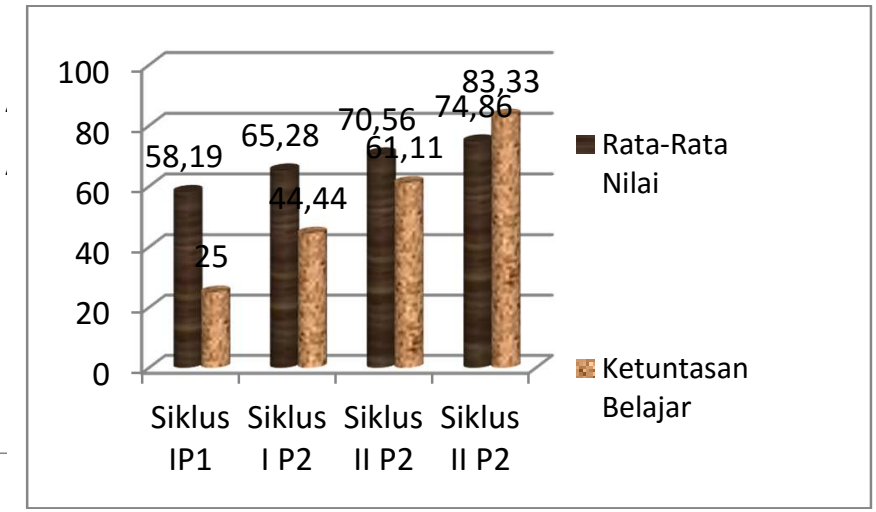

Gambar 2. Rekapitulasi Rata-rata Nilai dan Ketuntasan Hasil Tes Belajar Siswa Siklus I dan Siklus II

\section{Kendala yang Dihadapi dalam Penerapan Teknik Bertanya dalam Pembelajaran PKn Berbasis Masalah Sosial Untuk Meningkatkan aktivitas Belajar Siswa}

Dalam penerapan teknik bertanya dalam pembelajaran PKn berbasis masalah sosial yang dilaksanakan di kelas VII A, peneliti mengalami beberapa kendala. Hambatan atau kendala yang dialami oleh peneliti terjadi pada saat pelaksanaan tindakan 
proses pembelajaran berlangsung. Kendala-kendala tersebut diantaranya:

Kendala pertama yang dihadapi dalam penerapan teknik bertanya dalam pembelajaran PKn berbasis masalah sosial untuk meningkatkan aktivitas belajar siswa yaitu keadaan situasi ruangan yang tidak kondusif sehingga peneliti merasa tidak nyaman dengan keadaan ruangan yang ribut. Peneliti sulit untuk merubah suasana belajar dan kebiasaan belajar yang pasif, monoton dan hanya terfokus pada guru saja. Interaksi antara peneliti dan siswa sulit dilakukan karena siswa merasa asing dengan proses penerapan teknik bertanya yang peneliti lakukan. Dalam melakukan pengembangan pembelajaran di kelas peneliti mengalami kesulitan karena siswa tidak aktif dan kurang merespon terhadap materi yang peneliti berikan karena siswa sudah terbiasa dengan proses belajar satu arah dengan hanya mendengarkan materi yang diberikan oleh guru tanpa dibiasakan untuk bertanya ataupun mengungkapkan pendapat.

Kendala kedua siswa tidak terbiasa dengan proses pembelajaran yang kritis dan membahas masalah sosial yang dibawa ke dalam kelas, sehingga kegiatan proses belajar menjadi pasif. Siswa tidak dibiasakan diberi tugas untuk mencari masalah-masalah apa saja yang sedang hangat terjadi saat ini dengan kata lain siswa kurang dalam pengetahuan secara umum, siswa kurang menonton televisi yang sifatnya berita.

Kendala yang ketiga yaitu sebagian besar siswa tidak mempunyai buku paket sebagai sumber belajar, hal ini dapat mempersulit pemahaman materi yang diberikan, karena buku paket merupakan hal yang sangat penting bagi kegiatan belajar, siswa yang memiliki buku paket hanya 4 sampai 5 orang saja, sedangkan buku Lembar Kerja Siswa (LKS) sebagian besar siswa memilikinya.
Berdasarkan paparan di atas dapat terlihat bahwa pembelajaran harus lebih menekannkan pada aktivitas siswa dalam proses berfikir yang diarahkan oleh guru sebagai fasilitator untuk memperbaiki dan meningkatkan kemampuan berfikir siswa, dan membangun suasana yang aktif. Dalam hal ini masih banyak kendala yang dihadapi oleh peneliti dalam Penerapan Teknik Bertanya dalam Pembelajaran PKn berbasis masalah sosial yang dilaksanakan di kelas VII A. Hal lain yang sangat menunjang terhadap keberhasilan pembelajaran yaitu, apabila semua fasilitas sekolah dapat terpenuhi dengan baik karena hal ini merupakan faktor yang mempengaruhi pembelajaran.

Melihat banyaknya kendala tersebut, maka peneliti dan guru mitra sebagai pengelola kelas harus dapat meminimalisir kendala atau hambatan tersebut. Dengan meminimalisir kendala yang terjadi suasana belajar akan efektif, siswa akan lebih termotivasi dalam belajar dan dapat menciptakan interaksi positif yang baik antara siswa dan guru yang dapat mengarahkan pada proses pemberlajaran aktif dengan bersama-sama memecahkan masalah yang terjadi di dalam kelas dengan mencari solusi yang baik antara siswa dan guru agar tercipta suasana belajar yang aktif, dan kondusif.

\section{Upaya untuk Mengatasi Hambatan atau Kendala yang Dihadapi dalam Penerapan Teknik Bertanya dalam Pembelajaran PKn Berbasis Masalah Sosial}

Berdasarkan pengamatan di lapangan dengan melihat berbagai kendala yang dihadapi dan fakta yang ada ketika peneliti menerapkan penerapan teknik bertanya dalam pembelajaran PKn berbasis masalah sosial maka diperlukan upaya untuk mengatasi kendala tersebut. Kendala yang dihadapi oleh guru maupun peneliti yaitu berkenaan dengan masalah pengelolaan kelas dan masalah administrasi. Masalah 
yang dihadapi guru maupun peneliti dalam pengelolaan kelas dapat dikatakan sebagai kendala dalam proses pembelajaran, sehingga guru harus mampu mengidentifikasi dan memecahkan masalah tersebut.

Dari paparan di atas dapat diketahui bahwa kemampuan guru memegang peranan yang sangat penting, dalam kegiatan belajar mengajar, guru harus mempunyai berbagai strategi dalam mengajar agar proses pembelajaran menjadi aktif dan berjalan dengan tujuan yang ingin dicapai.

Adapun upaya yang dilakukan guru dan peneliti dalam menghadapi kendala yang terjadi di dalam kelas dalam penerapan teknik bertanya pada pembelajaran PKn berbasis masalah sosial di kelas VII A, diantaranya yaitu:

1. Rencana Pelaksanaan Pembelajaran (RPP) perlu di susun dengan baik dan matang, dalam hal materi, media, metode pembelajaran, maupun evaluasi sehingga membantu guru dalam pelaksanaan proses belajar mengajar di dalam kelas agar kegiatan belajar menjadi tidak kaku dan arah tujuan yang ingin di capai lebih jelas. Maka dengan itu guru berusaha lebih baik dalam menyelesaikan administrasi seperti pembuatan Silabus dan Rencana Pelaksanaan Pembelajaran (RPP), serta dalam pembuatan media pembelajaran yang dapat membantu guru maupun siswa dalam pemahaman materi yang akan di berikan.

2. Guru berusaha membangun suasana kelas yang demokratis, kondusif, aktif dan menyenangkan, misalnya dengan memberikan kesempatan kepada siswa untuk bertanya maupun berpendapat serta menyanggah pendapat dari temannya, hal itu menanamkan dan membiasakan siswa untuk belajar aktif dan kritis dalam menghadapi masalah-masalah sosial yang terjadi dan melatih keterampilan kewarganegaraan (civic skill) siswa. Maka dari itu guru berusaha lebih professional lagi dalam menjalankan perannya sebagai fasilitator maupun sebagai guru di kelas.

3. Guru berusaha mendalami metode penerapan teknik bertanya dalam pembelajaran PKn berbasis masalah sosial agar guru dapat menginformasikan kembali kepada siswa sehingga guru dan siswa melakukan langkah-langkah pembelajaran dengan penerapan teknik bertanya dalam pembelajaran PKn berbasis masalah social untuk meningkatkan aktivitas belajar siswa, hal ini dapat membuat siswa termotivasi untuk lebih mengetahui dan berfartisifasi aktif dalam mencari solusi masalah yang terjadi di dalam kelas.

4. Guru berusaha aktif dalam memotifasi siswa untuk lebih kritis dalam hal bertanya, berpendapat, menyanggah pendapat dari orang lain dan menanggapi masalah sosial yang terjadi saat ini. Siswa di latih untuk lebih aktif dan kritis dalam menanggapi masalah. Selain itu memotivasi siswa untuk menciptakan suasana kelas yang demokratis, aktif, dan kondusif sehingga proses belajar mengajar menjadi menarik dan aktif. Dalam hal ini guru berusaha meningkatkan kreatifitas terutama dalam hal pemilihan metode pembelajaran maupun media pembelajaran yang berbeda dan menarik, sehingga siswa lebih fokus dalam penyampaian materi yang diberikan oleh guru, proses belajar mengajar pun akan lebih menyenangkan.

\section{KESIMPULAN DAN SARAN}

Berdasarkan hasil penelitian di lapangan, maka diperoleh kesimpulan umum bahwa 
dengan penerapan teknik bertanya dalam pembelajaran PKn berbasis masalah sosial mampu meningkatkan aktivitas belajar siswa di kelas VII A SMP Negeri 1 Cikoneng, kegiatan belajar mengajar menjadi aktif dan menanamkan siswa untuk lebih berani dalam bertanya maupun mengemukakan pendapat.

Disamping kesimpulan umum tersebut tadi, peneliti juga memberikan kesimpulan khusus diantaranya adalah sebagai berikut:

Berdasarkan penelitian yang telah dilakukan, maka dapat diketahui bahwa:

1. Perencanaan yang dilakukan untuk merangsang siswa dalam penerapan teknik bertanya dalam pembelajaran PKn berbasis masalah sosial yaitu dengan melakukan strategi pembelajaran melalui diskusi dan debat, hal ini membuktikan adanya peningkatan aktivitas belajar siswa, baik menyimak, bertanya, menjawab pertanyaan maupun memberikan sanggahan terhadap siswa lain dalam pembelajaran Pendidikan kewarganegaraan (PKn).

2. Dalam implikasinya metode penerapan teknik bertanya dalam pembelajaran PKn berbasis masalah sosial adalah merupakan strategi pembelajaran yang dapat meningkatkan aktivitas belajar siswa karena melatih keterampilan dan menumbuhkan keberanian siswa untuk bertanya, berpendapat, menyanggah pendapat orang lain dan berfikir kritis - analitis melalui partisipasi siswa secara aktif dengan melatih siswa untuk memecahkan masalah-masalah sosial yang terjadi.

3. Hambatan atau kendala yang dihadapi dalam penerapan teknik bertanya dalam pembelajaran PKn berbasis masalah sosial yaitu siswa masih belum terbiasa dengan model pembelajaran teknik bertanya, siswa masih malu-malu untuk mengajukan pertanyaan, serta kesulitan dalam membangun suasana kelas yang aktif dan demokratis.

4. Upaya untuk mengatasi hambatan atau kendala yang dihadapi dalam penerapan teknik bertanya adalah (a) berusaha membangun suasana kelas yang aktif dengan cara memotivasi siswa dan memberikan nilai tambahan atau point kepada siswa yang bertanya atau yang mengemukakan pendapatnya, (b) membahas masalah sosial yang sedang hangat terjadi di luar lingkungan sekolah melalui media televisi, radio atau media cetak, dikaitkan terhadap materi yang akan dibahas dengan melakukan strategi pembelajaran yang menarik seperti diskusi dan debat, (c) memilih dan menuliskan topik yang menarik dan dapat memotivasi siswa untuk terlibat aktif dalam pembelajaran PKn, kemudian memunculkan wacana yang menimbulkan pertanyaan-pertanyaan yang kritis.

Berdasarkan kesimpulan di atas, maka peneliti mengemukakan beberapa saran yang mudah-mudahan dapat bermanfaat, diantaranya yaitu:

\section{Bagi Guru}

- Guru diharapkan agar selalu berusaha untuk senantiasa memperbaiki proses pembelajaran dengan memecahkan permasalahan-permasalahan yang dihadapi dalam pembelajaran PKn dan terus meningkatkan kualitas mengajarnya dengan memperbaiki metode atau strategi yang digunakan oleh guru, karena metode dan strategi pembelajaran sangat penting dalam mempengaruhi respon siswa dan motivasi siswa untuk menggali keterampilan kewarganegaraan (civic skills) dan membangun suasana pembelajaran yang demokratis,aktif. 
- Guru diharapkan dapat menggali kemampuan siswa dalam bertanya dan berpendapat dengan meningkatkan motivasi siswa untuk aktif dalam kegiatan pembelajaran pendidikan kewarganegaraan (PKn).

2. Bagi Siswa

1) Siswa sebaiknya harus lebih berfikir kritis terhadap masalahmasalah sosial yang sedang terjadi dengan menambah pengetahuan dari media cetak maupun media elektronik, agar siswa memiliki kemampuan berfikir yang luas dan mendalam, tidak hanya terfokus pada materi yang ada dalam buku pegangan siswa.

2) Siswa sebaiknya dapat menumbuhkan motivasi berfikir kritis yang ada dalam dirinya seperti bertanya dan berpendapat, sehingga dapat berpartisipasi aktif dalam proses pembelajaran Pendidikan Kewarganegaraan (PKn).

3. Bagi Sekolah

1) Sekolah hendaknya memberikan dukungan terhadap pelaksanaan peningkatan mutu pendidikan, yaitu dengan memberikan pelatihan-pelatihan terhadap guru mata pelajaran seperti seminar, diskusi antara guru mata pelajaran, dan pelatihan lainnya yang menunjang terhadap pembelajaran.

2) Memperbaiki fasilitas/sarana dan prasarana karena hal tersebut sangat menunjang terhadap kegiatan belajar mengajar, agar proses pembelajaran berjalan dengan baik.

\section{Daftar Pustaka}

[1] Angkowo dan Kosasih. A. (2007) Optimalisasi Media Pembelajaran
Mempengaruhi Motivasi, Hasil Belajar dan Kepribadian. Jakarta: PT Grasindo.

[2] Budiningsih, Asri. (2005). Belajar dan Pembelajaran. Jakarta: Rineka Cipta.

[3] Dahar. R.W. (1996). Teori-Teori Belajar. Jakarta: Erlangga.

[4] Djahiri, A. Kosasih. (1985). Strategi Pengajaran Afektif-Nilai-Moral-VCT dan Games dalam VCT. Bandung: Jurusan PMPKN IKIP.

[5] Djahiri, A. Kosasih. (1994/1995). Dasar-Dasar Umum Metodologi dan Pengajaran Nilai-Moral PVCT. IKIP Bandung.

[6] E. Mulyasa, M.Pd. (2009). Praktik Penelitian Tindakan Kelas. Bandung: PT. Remaja Rosdakarya.

[7] Fathoni, Abdurahmat. (2006). Metode Penelitian dan Teknik Penyusunan Skripsi. Jakarta: Rineka Cipta.

[8] Gulo, W. (2005). Strategi Belajar Mengajar. Jakarta: PT. Grasindo.

[9] Hamalik, Oemar. (2003). Pendekatan Baru Strategi Belajar Mengajar Berdasarkan CBSA. Bandung: Sinar Baru Algesindo.

[10]Jurusan PMPKN FPIPS UPI. (2005). Jurnal Civicus "Implementasi KBK Pendidikan Kewarganegaraan dalam Berbagai Konteks". Jurusan PKn FPIPS UPI Bandung.

[11]Kunandar. (2008). Langkah Mudah Penelitian Tindakan Kelas sebagai Pengembangan Profesi Guru. Jakarta: Rajawali Press.

[12]Moleong, J. Lexy. (2008). Metodologi Penelitian Kualitatif. Bandung: PT. Remaja Rosdakarya.

[13]Munandar Utami. (2002). Kreativitas dan Keterbakatan. Jakarta: PT Gramedia Pustaka Utama.

[14]Nasution, S. (2005). Berbagai Pendekatan dalam Proses Belajar dan Mengajar. Jakarta: Bumi Aksara.

[15]Nazir, M. (1999). Metode Penelitian. Jakarta: Ghalia Indonesia.

[16]Nurhadi. (2003). Pendekatan Kontekstual (Contextual Teaching and 
Learning $(C T L))$. Jakarta: Departemen Pendidikan Nasional.

[17]Nursisto, (2001), Spektrum Pengalaman Lapangan dalam Dunia Pendidikan. Jakarta: Proyek Pengembangan Sistem dan Standar Pengelolaan Sekolah Menengah Umum. [18]Rochiati, Wiriaatmadja, (2005). Metode Penelitian Tindakan Kelas. Bandung: PT Remaja Rosdakarya.

[19]Sunaryo, (1989). Strategi Belajar Mengajar Dalam Pembelajaran. Jakarta: DEPDIKBUD DITJEN DIKTI P2LPTK.

[20]Sudjana, D. (2000). Strategi Pembelajaran. Bandung: Falah Production.

[21]Sudjana, Nana. (2000). Dasar-dasar Proses Belajar Mengajar. Bandung: Sinar Baru Algesindo.

[22]Sanjaya, Wina. (2008). Strategi Pembelajaran. Jakarta: Kencana Prenada Media Grup.

[23] Sapriya. (2002). Studi Sosial Konsep dan Model Pembelajaran. Bandung: Buana Nusantara.

[24]Sapriya dan Udin, S. Winataputra. (2003). Pendidikan Kewarganegaraan: Model Pengembangan Materi dan Pembelajaran, Bandung: Laboratorium PKn FPIPS UPI.

[25]Sudjana, Nana. (2002). Dasar-dasar Proses Belajar Mengajar. Bandung: Sinar Baru Algesindo.

[26]Sugiyono. (2007). Metode Penelitian Kuantitatif Kualitatif dan $R \& D$. Bandung: Alfabeta.

[27]Surtosubroto. (2002). Proses Belajar Mengajar Di Sekolah. Jakarta: PT Rineka Cipta.

[28]Wiriaatmaja, Rochiati. (2008). Metode Penelitian Tindakan Kelas. Bandung: PT. Remaja Rosdakarya.

[29]Wuryan, Sri \& Syaifullah. (2008). Ilmu Kewarganegaraan (Civics). Bandung: Laboratorium Pendidikan Kewarganegaraan Universitas Pendidikan Indonesia. 